\title{
ÁREAS DEGRADADAS POR LAVRA DE AREIA - SUGESTÕES PARA MONITORIAMENTO
}

I.M.Souza

Jazidas de areia, contendo cascalho e silte, de pequenas dimensões (aproximadamente $75.000 \mathrm{~m}^{2}$ ) e pequeno volume (ao redor de $600.000 \mathrm{~m}^{3}$ ) constituem possivelmente o maior número de lavras existentes no Estado de São Paulo. Operam extração do tipo cava pelo método de sucção sob lâmina d'água de $8 \mathrm{~m}$ em média de espessura (às vezes até $30 \mathrm{~m}$ ), de onde se retiram 8 metros de espessura de areia (há casos de até $30 \mathrm{~m}$ ). São lavradas em regiões de várzeas, ao mesmo nivel topográfico e próximas aos rios que deram origem a esses depósitos aluviais, através das bácias de inundação. Se os regimes de explotação se mantiverem em média de $30.000 \mathrm{~m}^{3} / \mathrm{ano}$ ou $2.500 \mathrm{~m}^{3} / \mathrm{mês}$, a vida útil dessas jazidas seria estimada em 20 anos. Como o cronograma de recuperação da área demandará os mesmos 20 anos, e tomando-se como premissa que o tamanho do empreendimento não seja argumento para isenção de preocupação em causar poluição, deve-se dar especial atenção ao monitoramento.

Nos usos potenciais para a área a ser recuperada devido à formação de lagoas, as aptidões para a futura utilização são reduzidas. $O$ aterramento parece ser o método mais antieconômico e, a solução final "lagoa despoluída" parece a mais visualmente agradável. Ambas soluções devem ser analizadas do ponto de vista poluição, tanto a deposição de possível entulho ou a preservação de água durante 20 anos.

O objetivo do presente trabalho não é discutir o futuro potencial para as áreas recuperadas mas o monitoramento que o empreendimento deverá apresentar e seu cronograma tendo em vista principalmente a qualidade das águas, através de um sistema de controle que vise preservar a qualidade da lagoa, ou a qualidade do fréatico da "lagoa entulhada". Estuda-se acompanhar a percolação dos elementos contidos na água do rejeito da lavra da cava, em direção ao rio adjacente,

Departamento de Geologia Econômica e Geofísica Aplicada, Instituto de Geociências, USP. 
apesar de não se prever na lavra ou beneficiamento a adição de produtos químicos diferentes do óleo combustivel e lubrificantes usualmente utilizados nos equipamentos de extração. 